\title{
Organic acid coated-slow-release phosphorus fertilizers improve $P$ availability and maize growth in a tropical soil
}

\author{
Rafael da Silva Teixeira ${ }^{1 *}$, Ivo Ribeiro da Silva ${ }^{1}$, Rodrigo Nogueira de Sousa ${ }^{1}$, Edson \\ Márcio Mattiello', Emanuelle Mercês Barros Soares ${ }^{1}$
}

${ }^{1}$ Soil Science Department, Federal University of Viçosa, Av. PH Rolfs, s/n, Campus, Viçosa, MG, 36570-900, Brazil.Correspondingauthor: teixeiramarky@yahoo.com.br

\begin{abstract}
In this paper, we report the results of studies on the solubility (water solubility trial) and the response by plants (greenhouse pot experiment using Zea mays) for four types of monoammonium phosphate fertilizers (Conventional MAP - MAP 1 , MAP coated with a natural organic acid - $\mathrm{MAP}_{2}$, MAP coated with a synthetic organic acid - $\mathrm{MAP}_{3}$, and MAP coated with a peat humic organic acid - $\mathrm{MAP}_{4}$ ) applied at five increasing doses $\left(0,100,300,600\right.$ and $\left.1200 \mathrm{mg} \mathrm{P} \mathrm{dm}^{-3}\right)$ and pre-incubated with the soil for five lengths of time before planting $(0,15,30$ and $60 \mathrm{~d})$. The coating with organic acids reduced the water solubility of the P fertilizers - MAP provided a more gradual release of $\mathrm{P}$ over time. In the soil pot experiment, it was found that $\mathrm{MAP}_{1}$ required the highest dose to reach $90 \%$ of dry matter accumulation by the maize plant, followed by the Coated-Slow-Release Fertilizers (CSRF). The agronomic efficiency (AE) of P applied as the CSRF was 3 to $13 \%$ greater than that of $\mathrm{MAP}_{1}$. In addition, $\mathrm{MAP}_{4}$ led to higher values of $\mathrm{AE}(+11 \%)$ and apparent $\mathrm{P}$ recovery by maize $(+41 \%)$ in comparison to $\mathrm{MAP}_{1}$. The physicochemical properties imposed by the chemical composition of the organic acid coatings generated fertilizers with distinct release rates and improved agronomic efficiencies.
\end{abstract}

Keywords: P uptake, Agronomic efficiency, MAP.

\section{Introduction}

The need for more productive agricultural systems has required technological innovations that increase the efficiency of used inputs (Chien et al., 2009). The management of phosphate fertilizers is a key factor in crop production, which is especially the case in highly weathered tropical soil. However, in more oxidic tropical soils, the acquisition of $\mathrm{P}$ by plants is usually limited due to soil sorption processes (Novais and Smyth, 1999; Novais et al., 2007; Abdala et al., 2015a), usually requiring $\mathrm{P}$ application rates that are as much as 10 times larger than the actual plant demands or more (Novais and Smyth, 1999). 
Additionally, in recent years the application of $\mathrm{P}$ in medium to large-scale farms in Brazil has been used as a pre-planting operation (usually broadcast) in order to optimize the performance of the row crop planter (only seeds are actually planted). This strategy may reduce $\mathrm{P}$ availability if high solubility $\mathrm{P}$ fertilizers are used because of the increased contact time of fertilizer P to oxidic clay minerals. These soil minerals are known to form high stability, low reversibility bonds to P (Parfit, 1978), and more recent work using K-edge EXAFS with a synchrotron light source has shown that under low P concentrations, a stable monodentate surface complex is more likely to occur, although the formation of surface precipitates at higher concentrations of $\mathrm{P}$ in the goethite/water interface has also been demonstrated (Abdala et al., 2015a).

Given the relevance in $\mathrm{P}$ sorption processes, research efforts have been dedicated to understanding the effect of the contact time of $\mathrm{P}$ with soil components. Earlier studies with highly weathered soils indicated that $75 \%$ of $\mathrm{P}$ adsorption occurred within $30 \mathrm{~min}$ of contact for those soils with higher $\mathrm{P}$ adsorption capacity (Gonçalves et al., 1985). Santos et al. (2011) found that adsorption of $74 \%$ of the added $\mathrm{P}$ occurred within $5 \mathrm{~min}$ in soil with a high $\mathrm{P}$ sorption capacity $\left(0.3473 \mathrm{mg} \mathrm{g}^{-1}\right)$. More recently, Guedes et al., (2016) studying $\mathrm{P}$ adsorption and desorption kinetics using a stirred-flow system, observed that most of the P adsorption process occurs in the first minutes of contact with the solution. The reversibility of this process (P desorption) is rather limited in highly weathered tropical soils as result of the rapid formation of strong and stable bonds of phosphate ions with soil colloids, such as Fe-oxides (Abdala et al. 2015b).

Based on accumulating experimental evidence, it is not surprising that the longer the contact of fertilizer $\mathrm{P}$ to highly weathered soils, the greater the adsorption and the lower the availability of $\mathrm{P}$ to plants. Among the several strategies based on the soil-rhizosphere- plant continuum that could be used to improve $\mathrm{P}$ availability and P use efficiency (Shen et al., 2011), the use of slow-release coated phosphate fertilizers has gained recognition (McLaughlin et al., 2011). Research is increasingly being aimed at developing new technologies to supply plants with phosphorus in a slow manner. Among these slow-release fertilizers (SRF), the major categories are fertilizers coated with different materials. Recently, a number of materials have been tested: biodegradable polymers (Wu and Liu, 2008; Ao et al., 2013; Jia et al., 2013; Lubkowski et al., 2015), superabsorbent polymers (Liang et al., 2007; Teodorescu et al., 2009), commercial polymers (Figueiredo et al., 2012; Silva et al., 2012; Ma et al., 2013), oxides (Zhang et al., 2014) and fly ash (Dong et al., 2016). More specifically for MAP, a previous study has shown that when $\mathrm{P}$ is more slowly released from a thin polymer coated-MAP fertilizer granule, it increased $\mathrm{P}$ availability, $\mathrm{P}$ uptake and $\mathrm{P}$ use efficiency by barley plants (Pauly et al., 2002). The polymercoated fertilizers had a greater effect on late plant growth stages, whereas the commercial MAP fertilizer was more favorable for P uptake and plant growth at the beginning of the experiment. These results led us to surmise that coated slow-release fertilizers (CSRFs) may be more effective in applications before planting than uncoated conventional MAP if the soil has a large $\mathrm{P}$ adsorption capacity. However, to date, there is a scarcity of information to back up such a hypothesis.

The ideal CSRF should control the release rate of nutrients according to different environmental conditions, prevent the accumulation of undesirable synthetic residues in the soil and minimize the frequency and dose of fertilizer applications. However, it is difficult to find a coating material that enables these features. Many researchers report that the molecular composition of coating materials used in CSRFs have influence over P release (Wu and Liu, 2008; Tyliszczak et al., 2009; Jia et al., 2013; Ahmad et al., 2015). 
In this context, organic polymers are a promising coating material because they are easily degradable and non-toxic to the environment. Although there are many studies that demonstrate the CSRF water dissolution rate (Bortolin et al., 2012; Lubkowski, 2014; Lubkowski et al., 2015; Ahmad et al., 2015) and agronomic efficiency (Pauly et al., 2002; Figueiredo et al., 2012; Silva et al., 2012; Chagas et al., 2015), little is known about the characteristics of organic polymers that could reduce the negative effects of previous fertilizer P contact time with soil on P availability and the consequent growth response by the plant.

Thus, the purpose of this study was to investigate two commercial CSRFs coated with organic polymers (organic acids) and a CSRF coated with a peat humic organic acid in the laboratory. The kinetic parameters of $P$ release were determined, and the responses of maize plants to different doses and pre-application times (previous fertilizer P contact with soil) were evaluated.

\section{Materials and Methods}

\subsection{Monoammonium phosphate (MAP) coating}

An uncoated commercial monoammonium phosphate fertilizer $\left(\mathrm{MAP}_{1}, 52 \% \mathrm{P}_{2} \mathrm{O}_{5}\right)$ and three coated monoamonium phosphate formulations were tested. The size range of MAP granules was standardized to 2 to $3 \mathrm{~mm}$ diameter each. The slow release MAP fertilizers were obtained by coating with a distinct organic acid, i.e., $\mathrm{MAP}_{2}\left(50 \% \mathrm{P}_{2} \mathrm{O}_{5}\right.$ was coated with a natural organic acid), $\mathrm{MAP}_{3}\left(48 \% \mathrm{P}_{2} \mathrm{O}_{5}\right.$ was coated with a synthetic organic acid, which is commercially available as Kimcoat PTM from Kimberlit Agrociências, Olimpia, SP, Brazil) and $\mathrm{MAP}_{4}\left(43 \% \mathrm{P}_{2} \mathrm{O}_{5}\right.$ was coated with a humic acid extracted from peat). Coated $\mathrm{MAP}_{2}$ and $\mathrm{MAP}_{3}$ were obtained from Kimberlit, and the $\mathrm{MAP}_{4}$ coating was prepared in our laboratory.
The humic organic acid was extracted from peat (Arraial do Cabo, RJ-Brazil) using an alkaline procedure with further purification as in Swift (1996). The coating of $\mathrm{MAP}_{4}$ with a peat humic organic acid was initially carried out by stirring $2 \%(\mathrm{w} / \mathrm{w})$ soybean cooking oil with $\mathrm{MAP}_{1}(10 \mathrm{~g})$ for $5 \mathrm{~min}$. Then, lyophilized peat humic acid $(1.5 \mathrm{~g})$ was added and stirred in a rotary shaker for $15 \mathrm{~min}$. The MAP fertilizer was weighted before and after coating with humic acid. A mass of $0.61 \mathrm{~g}$ ( $41 \%$ of added peat humic organic acid) was adsorbed onto the conventional MAP ${ }_{1}$.

Spectral characterizations of organic acids samples used for coating of the MAP fertilizer were performed in the 500-4000 $\mathrm{cm}^{-1}$ region using a VARIAN 660 infrared spectrophotometer fitted with a total attenuated reflectance (PIKE GladiATR) accessory (Figure 1).

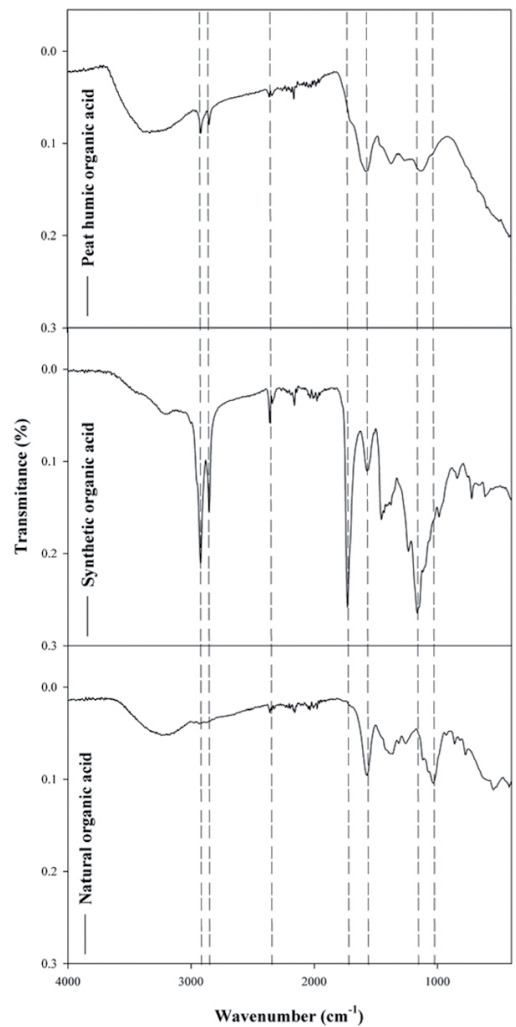

Figure 1. FTIR spectra of natural organic acid, synthetic organic acid and peat humic organic acid utilized in the coating of fertilizers 


\subsection{Kinetics of $P$ release in water}

A leaching column test was carried out to estimate $\mathrm{P}$ release from coated MAPs over 22 hours. Five grams of fertilizer were put into leaching columns, and a controlled flow of water at $2 \mathrm{~mL} \mathrm{~min}{ }^{-1}$ was applied at the top. Leachate samples were collected from 0 up to $22 \mathrm{~h}$, their volumes were measured, and $\mathrm{t}$ and $\mathrm{P}$ concentrations were determined colorimetrically based on the ascorbic acid method (Braga and Defelipo, 1974). The values of $P$ released over time were fitted with a pseudo-first order model according to the Lagergren equation (Equation 1).

$$
Q_{\mathrm{t}}=\mathrm{Qe}\left(1-e^{\mathrm{kt}}\right)
$$

Equation 1

where $Q_{t}$ is released fertilizer $\mathrm{P}$ and $Q_{e}$ is the fast release $\mathrm{P}$ pool at equilibrium time and at time $t$, respectively, and $\mathrm{k}_{l}$ is the rate constant of the pseudo-first order release.

Then, using the estimated values of $\mathrm{P}$ release rates $(k)$, it was possible to calculate the time required for $50 \%$ of the fertilizer $\mathrm{P}$ to be released $\left(\mathrm{t}_{1 / 2 P}\right)$, based on Paul and Clark (1996) (Equation 2).

$t_{1 / 2 P}=\ln (2) \mathrm{k}_{1}$

Equation 2.

\subsection{Greenhouse pot experiment}

Phosphate fertilizers were evaluated in a greenhouse pot experiment with maize plants. The soil was a clayey Oxisol (Typic Hapludox) collected from the 0-20 cm layer: $\mathrm{pH}$ (water): 5.00; $\mathrm{Ca}^{2+}: 0.27 \mathrm{cmol}_{\mathrm{c}} \mathrm{dm}^{-}$ 3; $\mathrm{Mg}^{2+}: 0.06 \mathrm{cmol}_{\mathrm{c}} \mathrm{dm}^{-3}$; P: $2.30 \mathrm{mg} \mathrm{dm}^{-3}$; CEC: 3.78 $\mathrm{cmol}_{\mathrm{c}} \mathrm{dm}^{-3}$; Equilibrium phosphorus (Alvarez et al., 2000): $8.10 \mathrm{mg} \mathrm{L}^{-1}$; Organic matter: $1.14 \%$; Clay: $80 \%$; Silt: $10 \%$ and Sand: $10 \%$. The soil was airdried and passed through a 2-mm sieve, and then 2.5 $\mathrm{dm}^{3}$ of homogenous soil was placed into plastic bags.
Lime $\left(\mathrm{CaCO}_{3}\right.$ and $\mathrm{MgCO}_{3}$ p.a. $(3: 1$ molar ratio) $)$ and a basal nutrient solution (Novais et al., 1991) were applied and mixed, and the soil was wetted to $80 \%$ of field capacity. Next, the soil was accommodated in 3 $\mathrm{dm}^{3}$ plastic pots.

A specific stainless apparatus was built to study phosphorus diffusion from the fertilizer dissolution zone into the soil without allowing direct contact of the roots with the fertilizer granules (Figure 2). The apparatus had two concentric cylindrical compartments (inner and outer) built with 0.25 and $1.0 \mathrm{~mm}$ mesh size stainless steel sieves, respectively. A defined amount of the four MAP fertilizers previously described were applied into the inner cylinder, and then the soil was accommodated inside the outer cylinder. The apparatus was then inserted into the pot soil. In a preliminary study, we observed that maize plant roots could access the outer cylinder soil (data not shown) and P, but they could not access fertilizer $P$ inside the inner cylinder where the MAP granules were located (Figure 2).

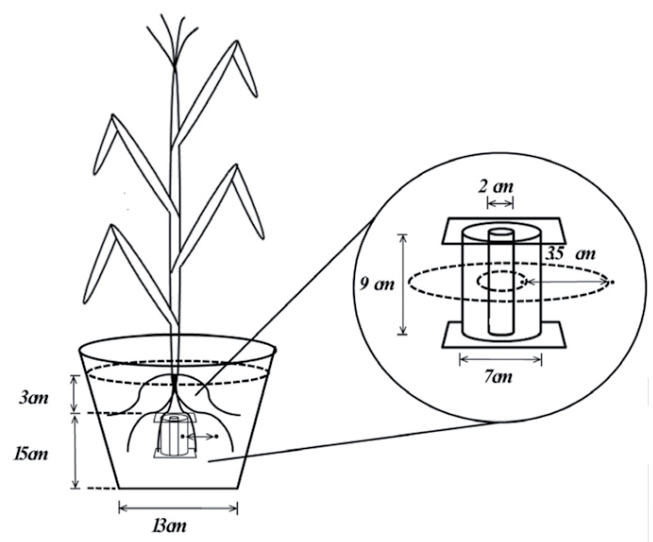

Figure 2. Scheme of experimental unit (pot with plants) and apparatus used to study phosphorus diffusion. By applying granular phosphate fertilizers into the inner cylinder and placing soil into the outer cylinder, roots can not access $\mathrm{P}$ directly from fertilizer granules. 
The fertilizers were applied at rates equivalent to 0 , $100,300,600$ and $1200 \mathrm{mg}$ of $\mathrm{P} \mathrm{dm} \mathrm{dm}^{-3}$ of soil in the whole pot. To simulate an early field pre-planting application (with the consequent increase in $\mathrm{P}$ contact time with the surface of soil particles), the four MAP fertilizers were applied into the inner cylinder and incubated under moist soil conditions for $0,15,30,60$ and $120 \mathrm{~d}$ before planting. Four seeds of Zea mays (DKB 390 hybrid) were planted in pots with $2.5 \mathrm{dm}^{3}$ of soil, and after germination and thinning, a single plant per pot was grown for $35 \mathrm{~d}$.

Treatments were arranged in a $4 \times 5 \times 5$ factorial scheme composed of the four MAP fertilizers $\left(\mathrm{MAP}_{1}\right.$, $\mathrm{MAP}_{2}, \mathrm{MAP}_{3}$ and $\left.\mathrm{MAP}_{4}\right)$, applied at four rates $(0$, $100,300,600$ and $1200 \mathrm{mg}$ of $\mathrm{P} \mathrm{dm}^{-3}$ of soil) and five incubation times before planting $(0,15,30,60$ and $120 \mathrm{~d}$ ). The experiment was carried out in a completely randomized block design with three replications.

\subsection{Chemical analysis}

At $35 \mathrm{~d}$ after planting, the maize plants were harvested. The roots were washed to remove soil particles prior to separation into roots and shoots. Then, they were dried in an oven at $65{ }^{\circ} \mathrm{C}$ for $72 \mathrm{~h}$, weighed and milled. Dried ground samples were digested with a nitric-perchloric solution (Johnson and U1rich, 1959), and the $\mathrm{P}$ in the extract was determined by the colorimetric ascorbic acid method (Braga and Defelipo, 1974). The soil that was inside the outer cylinder and that outside the apparatus (whole pot soil) were collected and homogenized separately, and a representative sample was taken for subsequent analysis. The distance between a midpoint in the outer cylinder and another located in the middle point between the apparatus and the pot wall (3.5 $\mathrm{cm}$ ) was used for calculating the difference in P concentrations at the two points in the soil (Delta P), and they were assumed to correspond to P movement by diffusion from the fertilizer dissolution zone to the whole pot soil. The available soil $\mathrm{P}$ was determined by the anion-exchange resin method (van Raij et al., 1987).

\subsection{Statistical analysis and agronomic indices}

Data were submitted to an analysis of variance, and the effects of fertilizer $P$ rates and incubation time on dry matter, $\mathrm{P}$ uptake by maize, available $\mathrm{P}$ in soil and soil Delta P for each MAP fertilizer were assessed through a linear regression analysis. Multiple linear regressions using Akaike's Information Criteria (AIC) were used to define the best fit model for each MAP fertilizer. Statistical analyses were run using SAS (SAS Institute, Inc. 2001).

Applied fertilizer $\mathrm{P}$ and available soil $\mathrm{P}$ concentration in the soil corresponding to $90 \%$ of maximum dry matter production were estimated using the selected regression models. The indices of Agronomic Efficiency (AE) and Apparent P Recovery (AR) of a plant were calculated as the ratio of the increase in dry matter production and the $\mathrm{P}$ taken up by the plant over control (no added P) treatments to the applied rate of the nutrient, respectively, as in the following equations:

$A E\left(m g m g^{-1}\right)=\left(Y_{N}-Y_{\partial}\right) / F_{N} \quad$ Equation 3.

$A R(\%)=\left[\left(U_{N}-U_{O}\right) / F_{N}\right] \times 100 \quad$ Equation 4.

where $\mathrm{Y}_{\mathrm{N}}$ and $\mathrm{U}_{\mathrm{N}}$ are the dry matter production and $\mathrm{P}$ taken up by plants in a given treatment, respectively, $\mathrm{Y}_{\mathrm{O}}$ and $\mathrm{U}_{\mathrm{O}}$ are dry matter production and $\mathrm{P}$ taken up by plants in the control treatment without $\mathrm{P}$ application, respectively, and $\mathrm{F}_{\mathrm{N}}$ is the amount of applied fertilizer P corresponding to $90 \%$ of the maximum dry matter production. 


\section{Results}

\subsection{Kinetics of P release from the fertilizer granule}

Coated MAP fertilizer granules released P to percolating water slower and in smaller amounts than the uncoated MAP $\left(\mathrm{MAP}_{1}\right)$ (Figure 3$)$. With percolating water for $1320 \mathrm{~min}$, approximately $96 \%$ of all the $\mathrm{P}$ was released from $\mathrm{MAP}_{1}$. On the other hand, $\mathrm{MAP}_{4}$ showed a distinctly slower release of $\mathrm{P}$ compared to $\mathrm{MAP}_{2}$ and $\mathrm{MAP}_{3}$ (Figure 3). $\mathrm{MAP}_{4}$ had a t $\mathrm{t}_{1 / 2 \mathrm{P}}$ of 204 min, while for the $t_{1 / 2 \mathrm{P}}$ of $\mathrm{MAP}_{2}$ and $\mathrm{MAP}_{3}$ were 56 and $41 \mathrm{~min}$, respectively. $\mathrm{MAP}_{1}$ released approximately $50 \%$ of the initial $\mathrm{P}$ in only $13 \mathrm{~min}$.

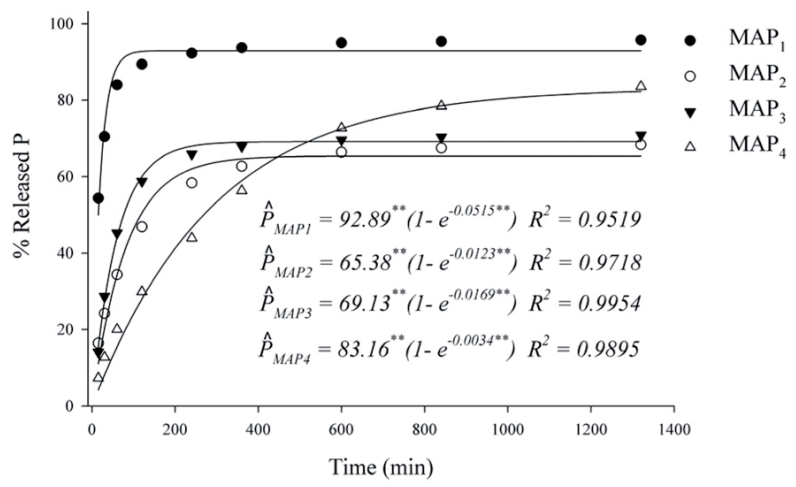

Figure 3. Release of P relative to total P released (\%) from non-coated MAP (MAP $\left.{ }_{1}\right)$ and coated MAP as a function of time (min) in a leaching column under water flow at $2 \mathrm{~mL} \mathrm{~min}^{-1}$. $\mathrm{MAP}_{2}$ is coated with a natural organic acid; $\mathrm{MAP}_{3}$ is coated with a synthetic organic acid and $\mathrm{MAP}_{4}$ is coated with a peat humic organic acid. Equations are adjusted according Lagergren. ** indicate significant coefficients at $p<0.01$ by the $\mathrm{t}$ test.

\subsection{FTIR spectrum of organic acids}

The FTIR spectrum of the organic acids used in the coating presented the following peaks in the wavenumbers with the possible assignment, respectively: $595 \mathrm{~cm}^{-1}((\delta \mathrm{s}(\mathrm{C}-\mathrm{CO}-\mathrm{C}))$ aldehydes$) ; 717$ and $827 \mathrm{~cm}^{-1}$ $(\mathrm{\gamma}(\mathrm{C}-\mathrm{H})$ aromatic ring $) ; 3350 \mathrm{~cm}^{-1}\left(\mathrm{v}_{\mathrm{s}}(\mathrm{O}-\mathrm{H})\right.$ in hydrogen bonding (related to alcohol, phenols or carboxylic acids)); 2844 and $2913 \mathrm{~cm}^{-1}\left(\mathrm{v}_{\mathrm{s}}\left(\mathrm{C}-\mathrm{H}, \mathrm{CH}_{2}\right)\right.$ and $\mathrm{v}_{\mathrm{s}}(\mathrm{C}-$ $\left.\left.\mathrm{H}, \mathrm{CH}_{3}\right)\right) ; 2350 \mathrm{~cm}^{-1}(\mathrm{vs}(\mathrm{C} \equiv \mathrm{C})$ conjugated alkynes $)$; $2159 \mathrm{~cm}^{-1}\left(\mathrm{v}_{\mathrm{s}}(\mathrm{C} \equiv \mathrm{N})\right.$ possibly in conjunction with other unsaturated groups); $1730 \mathrm{~cm}^{-1}\left(\mathrm{v}_{\mathrm{s}}(\mathrm{C}=\mathrm{O})\right.$ aldehydes and ketones); $1570 \mathrm{~cm}^{-1}\left(\mathrm{v}_{\mathrm{s}}(\mathrm{C}=\mathrm{C})\right.$ the benzene ring and the vibration of the aromatic skeleton; $v_{\text {as }}\left(\mathrm{COO}^{-}\right)$ and $v_{\mathrm{s}}(\mathrm{C}=\mathrm{O})$ the $\mathrm{COOH}$ group due to the $\mathrm{H}$ bonded
$\mathrm{OH} ; \mathrm{v}_{\mathrm{s}}(\mathrm{C}=\mathrm{C})$ overlaid with $\delta_{\mathrm{as}}\left(\mathrm{C}-\mathrm{H}, \mathrm{CH}_{3}\right)$; ring alkanes; $\mathrm{v}_{\mathrm{s}}(\mathrm{C}=\mathrm{N})$ pyrimidine); $1380 \mathrm{~cm}^{-1}(\delta \mathrm{s}(\mathrm{O}-\mathrm{H})$, $v_{\mathrm{s}}(\mathrm{C}-\mathrm{O})$ phenol groups and the $\left.\mathrm{v}_{\text {as }}\left(\mathrm{COO}^{-}\right)\right) ; 1365 \mathrm{~cm}^{-1}$ ( $\delta \mathrm{s}\left(\mathrm{C}-\mathrm{H}, \mathrm{CH}_{3}\right.$ or $\left.\mathrm{CH}_{2}\right)$ aliphatic chains); $1157 \mathrm{~cm}^{-1}$ $\left(\left(\mathrm{v}_{\mathrm{s}}(\mathrm{C}-\mathrm{CO}-\mathrm{C})\right)\right.$ aldehydes $)$ and $1100 \mathrm{~cm}^{-1}(\delta \mathrm{s}(\mathrm{O}-\mathrm{H})$ and $\mathrm{v}_{\mathrm{s}}(\mathrm{C}-\mathrm{O})$ coupled $\mathrm{v}_{\mathrm{s}}(\mathrm{C}-\mathrm{C})$ secondary alcohols).

The peat humic acid used for coating the $\mathrm{MAP}_{4}$ fertilizer had a lower density of aliphatic hydrocarbons (especially with smaller ramifications) and a greater density of - $^{-}{ }^{-}$and $-\mathrm{OH}$ groups when compared with the synthetic organic acid and the natural organic acid, respectively (Figure 1), giving it an intermediate hydrophobicity among the other organic acids. The synthetic organic acid $\left(\mathrm{MAP}_{3}\right)$ had a higher density 
of aliphatic hydrocarbons, with the presence of ramifications, unsaturated bonds $(\mathrm{C} \equiv \mathrm{C})$ (Figure 1), and carbonyl groups $(\mathrm{C}=\mathrm{O})$ (Figure 1). Additionally, it had less intense bands related to stretches of the $\mathrm{C}=\mathrm{C}$ aromatic ring (Figure 1) in its structure compared to the other organic acids. The presence of unsaturation promotes greater distortion in the molecule even if it has higher aliphatic chains. This feature and the greater number of carbonyl groups confer a higher permeability to water molecules. In contrast, the natural organic acid used for producing $\mathrm{MAP}_{2}$ showed no $\mathrm{C}-\mathrm{H}$ $\left(\mathrm{CH}_{2}\right)$ or $\mathrm{C}-\mathrm{H}\left(\mathrm{CH}_{3}\right)$ stretches, which are features of alkyl chains. Combined with the smaller abundance of - $\mathrm{COO}^{-}$groups and larger bands for $\mathrm{C}=\mathrm{C}$ stretches in the aromatic rings (Figure 1), this molecule displayed greater hydrophobicity.

\subsection{Greenhouse pot experiment}

Available P in soil

The uncoated conventional MAP $\left(\mathrm{MAP}_{1}\right)$ led to the lowest availability of $\mathrm{P}$ in the soil among all fertilizers when higher levels of $\mathrm{P}$ were applied (Figure 4). In this way, the maximum availability of $\mathrm{P}$ reached by applying uncoated MAP was $246 \mathrm{mg} \mathrm{dm}^{-3}$ when $1200 \mathrm{mg}$ of fertilizer $\mathrm{P} \mathrm{dm}^{-3}$ were applied $15 \mathrm{~d}$ before planting maize. The coated fertilizers favored greater availability of soil $\mathrm{P}$ over time. The coated $\mathrm{MAP}_{2}$ provided a more constant concentration of available soil $P$ over pre-incubation times among all fertilizers. The greatest availability of soil $\mathrm{P}$ when applying $\mathrm{MAP}_{2}$ $\left(267 \mathrm{mg} \mathrm{dm}^{-3}\right.$ ) occurred with $1200 \mathrm{mg}$ of $\mathrm{P} \mathrm{dm}^{-3}$ and no pre-incubation time ( $0 \mathrm{~d})$ (Figure 4$)$. A similar behavior of soil $\mathrm{P}$ availability over time was observed for both $\mathrm{MAP}_{3}$ and $\mathrm{MAP}_{4}$. The highest concentration of available soil $\mathrm{P}$ among all fertilizers was provided by $\mathrm{MAP}_{3}\left(359 \mathrm{mg} \mathrm{dm}^{-3}\right)$ and followed by $\mathrm{MAP}_{4}(324$ $\mathrm{mg} \mathrm{dm}{ }^{-3}$ ), both after $20 \mathrm{~d}$ of pre-incubation and with the application of the highest $\mathrm{P}$ dose $-1200 \mathrm{mg}$ of $\mathrm{P}$ $\mathrm{dm}^{-3}$ (Figure 4).

\subsection{Estimated P movement from the fertilizer gran- ules into the soil}

As expected, the Delta $\mathrm{P}$ (the difference in available soil $\mathrm{P}$ in the internal soil core in comparison to that in the external soil core) for all fertilizers increased with the applied level of P (Figure 5). The uncoated MAP showed a significant reduction in Delta P over time Table 1. The concentrations of available soil $\mathrm{P}$ were estimated to be similar for the two sampling points (Delta P: 0) after 33 and 85 d, by applying $100 \mathrm{mg} \mathrm{dm}^{-3}$ and $1200 \mathrm{mg} \mathrm{dm}^{-3}$, respectively (Figure 5). However, even the high application doses of coated $\mathrm{MAP}_{2}, \mathrm{MAP}_{3}$ and $\mathrm{MAP}_{4}$ were not sufficient to allow $\mathrm{P}$ movement from the internal core soil to the external core soil at the same magnitude as uncoated P. Thus, there was always a smaller amount of P movement in soil when coated MAP fertilizers were used compared to the uncoated conventional MAP. Nevertheless, it did not mean less P uptake and maize growth as one would initially suspect (see more details below). 

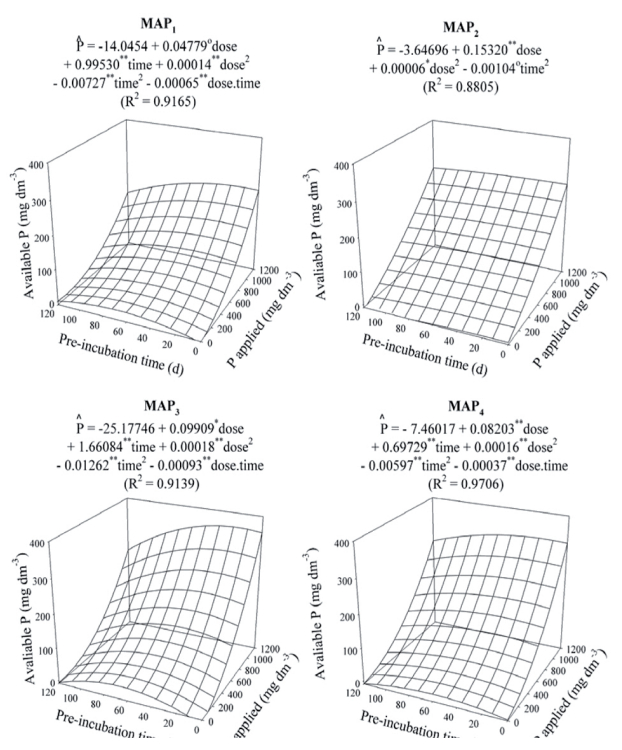

Figure 4. Available soil $\mathrm{P}$ extracted by anion-exchange resin $\left(\mathrm{mg} \mathrm{dm}^{-3}\right)$ as a function of applied P rates $\left(\mathrm{mg} \mathrm{dm}^{-3}\right)$ and pre-incubation times (d) of non-coated MAP $\left(\mathrm{MAP}_{1}\right)$ and coated MAP $\left(\mathrm{MAP}_{2}, \mathrm{MAP}_{3}\right.$ and $\left.\mathrm{MAP}_{4}\right) . \mathrm{MAP}_{2}$ is coated with a natural organic acid; $\mathrm{MAP}_{3}$ is coated with a synthetic organic acid; and $\mathrm{MAP}_{4}$ is coated with peat humic organic acid. ${ }^{\circ}, *, * *$ indicate significant coefficients at $p<0.1 ; 0.05$ and 0.01 by the $t$ test, respectively.

\subsection{Maize plants $P$ uptake}

The conventional uncoated MAP caused little variation in the uptake of P by the maize plant (Figure 6), regardless of the pre-incubation time. The maximum P uptake by the maize plant $\left(98.2 \mathrm{mg} \mathrm{pot}^{-1}\right)$ was the lowest among all MAP fertilizers evaluated, and it was estimated to occur when $1080 \mathrm{mg} \mathrm{dm}^{-3}$ of $\mathrm{P}$ as $\mathrm{MAP}_{1}$ was pre-incubated with the soil $120 \mathrm{~d}$ before planting (Figure 6). Interestingly, $\mathrm{MAP}_{4}$ allowed the
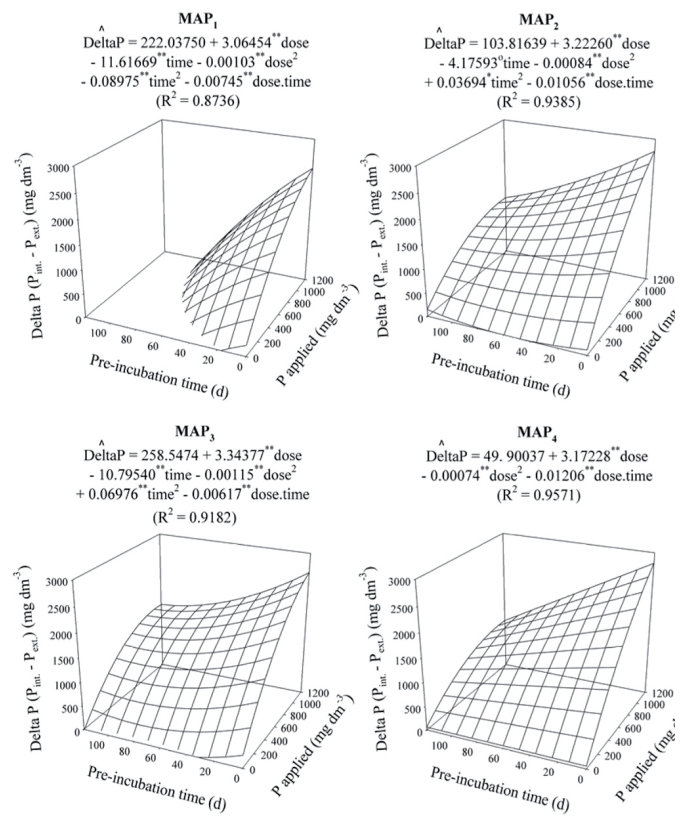

Figure 5. Differences between available P concentrations in the inner and outer soil compartments (Delta

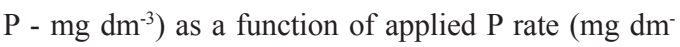
$\left.{ }^{3}\right)$ and pre-incubation time (d) of non-coated MAP $\left(\mathrm{MAP}_{1}\right)$ and coated MAP $\left(\mathrm{MAP}_{2}, \mathrm{MAP}_{3}\right.$ and $\left.\mathrm{MAP}_{4}\right)$. $\mathrm{MAP}_{2}$ is coated with a natural organic acid; $\mathrm{MAP}_{3}$ is coated with a synthetic organic acid; and $\mathrm{MAP}_{4}$ is coated with a peat humic organic acid. ${ }^{\circ}, *, * *$ indicate significant coefficients at $p<0.1 ; 0.05$ and 0.01 by the $\mathrm{t}$ test, respectively.

greatest $\mathrm{P}$ uptake by the maize plant (111.2 $\left.\mathrm{mg} \mathrm{pot}^{-1}\right)$. That uptake was estimated to occur with the application of $1080 \mathrm{mg} \mathrm{dm}^{-3}$ of $\mathrm{P}$ to the soil as MAP $46 \mathrm{~d}$ prior to the planting. $\mathrm{MAP}_{2}$ provided a $\mathrm{P}$ uptake by maize plants of $107 \mathrm{mg} \mathrm{pot}^{-1}$ when $1080 \mathrm{mg} \mathrm{dm}^{-3}$ of $\mathrm{P}$ pre-incubated with the soil during $84 \mathrm{~d}$ before planting. Finally, $\mathrm{MAP}_{3}$ allowed the lowest $\mathrm{P}$ uptake by the plants (98.6 $\mathrm{mg} \mathrm{pot}^{-1}$ ) among all the coated fertilizers, which was estimated to occur with its application (960 $\mathrm{mg} \mathrm{dm}^{-3}$ ) to the soil $84 \mathrm{~d}$ before planting. 
Table 1. Estimated values of $\mathrm{P}$ applied $\left(\mathrm{mg} \mathrm{dm}^{-3}\right)$ as uncoated $\left(\mathrm{MAP}_{1}\right)$ and coated $\mathrm{MAP}\left(\mathrm{MAP}_{2}, \mathrm{MAP}_{3}\right.$ and $\left.\mathrm{MAP}_{4}\right)$ and time of pre-incubation (d) to reach $90 \%$ of dry matter production (DMP, $\mathrm{g} \mathrm{pot}^{-1}$ ) of maize growth by $35 \mathrm{~d}$ in a pot experiment, and the corresponding available soil phosphorus concentration (Avail. soil $\mathrm{P}, \mathrm{mg} \mathrm{dm}^{-3}$ ), Delta $\mathrm{P}$ $\left(\mathrm{mg} \mathrm{dm}{ }^{-3}\right)$, agronomic efficiency $\left(\mathrm{AE}, \mathrm{mg} \mathrm{mg}^{-1}\right)$ and apparent recovery $(\mathrm{AR}, \%)$

\begin{tabular}{|c|c|c|c|c|c|c|c|}
\hline Fertilizers & $90 \%$ DMP & P applied & $\begin{array}{c}\text { Pre- } \\
\text { incubation } \\
\text { time }\end{array}$ & Avail. soil P & Delta P & $\begin{array}{l}\text { Agronomic } \\
\text { efficiency } \\
\text { (AE) }\end{array}$ & $\begin{array}{c}\text { Apparent } \\
\text { recovery } \\
\text { (AR) }\end{array}$ \\
\hline & $\ldots \operatorname{g~pot}^{-1} \ldots$ & $\ldots \mathrm{mg} \mathrm{dm}^{-3} \ldots$ & $\ldots \ldots \mathrm{d} \ldots \ldots$ & $\ldots \mathrm{mg} \mathrm{dm}^{-3} \ldots$ & $\ldots \mathrm{mg} \mathrm{dm}^{-3} \ldots$ & $\ldots . . . \mathrm{mg} \mathrm{mg}^{-1} \ldots$. & ........ $\%$ \\
\hline $\mathrm{MAP}_{1}$ & 30.41 & 1116 & 79 & 190 & 234 & 8.95 & 3.3 \\
\hline $\mathrm{MAP}_{2}$ & 23,87 & 765 & 69 & 144 & 1410 & $9.18(+3 \%)$ & $4.92(+49 \%)$ \\
\hline $\mathrm{MAP}_{3}$ & 26.85 & 840 & 55 & 195 & 1589 & $10.08(+13 \%)$ & $4.36(+32 \%)$ \\
\hline $\mathrm{MAP}_{4}$ & 26.61 & 825 & 53 & 173 & 1632 & $9.92(+11 \%)$ & $4.65(+41 \%)$ \\
\hline
\end{tabular}

$\mathrm{MAP}_{1}$ uncoated MAP; $\mathrm{MAP}_{2}$ is coated with a synthetic organic acid; $\mathrm{MAP}_{3}$ is coated with a natural organic acid and $\mathrm{MAP}_{4}$ is coated with a peat humic organic acid.

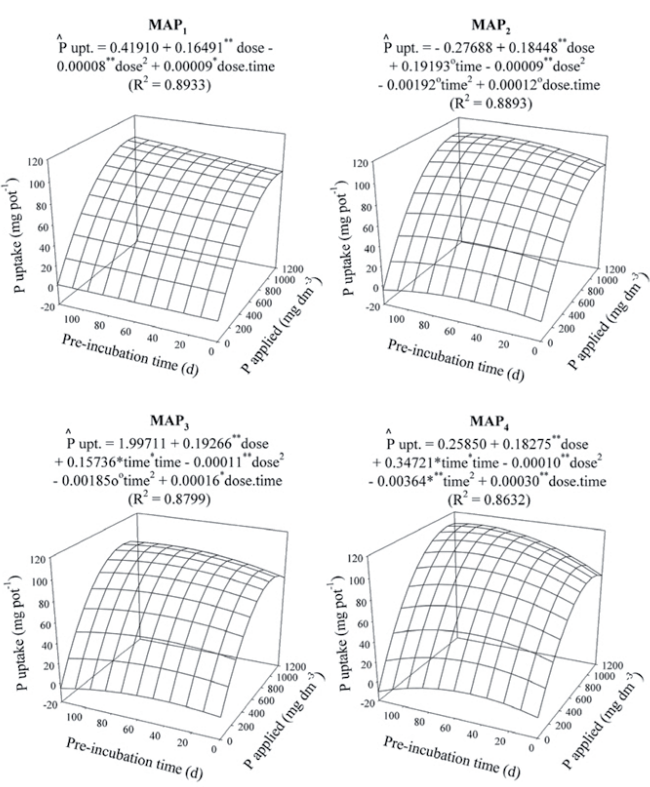

Figure 6. Phosphorus uptake $\left(\mathrm{mg} \mathrm{pot}^{-1}\right)$ by maize plants as a function of applied $\mathrm{P}$ rate $\left(\mathrm{mg} \mathrm{dm}^{-3}\right)$ and pre-incubation time (d) of non-coated $\mathrm{MAP}\left(\mathrm{MAP}_{1}\right)$ and coated MAP ( $\mathrm{MAP}_{2}, \mathrm{MAP}_{3}$ and $\left.\mathrm{MAP}_{4}\right) . \mathrm{MAP}_{2}$ is coated with a natural organic acid; $\mathrm{MAP}_{3}$ is coated with a synthetic organic acid; and $\mathrm{MAP}_{4}$ is coated with a peat humic organic acid. ${ }^{\circ}, *, * *$ indicate significant coefficients at $p<0.1 ; 0.05$ and 0.01 by the $\mathrm{t}$ test, respectively

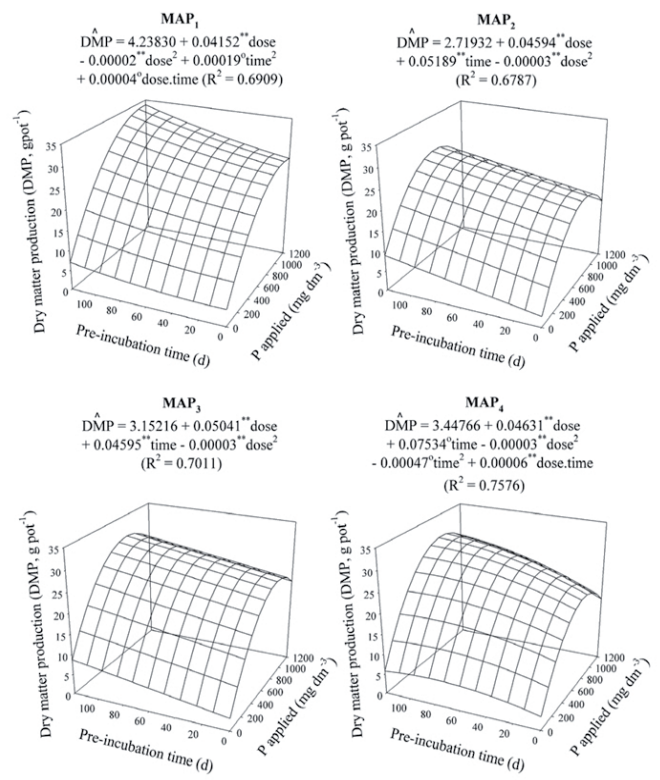

Figure 7. Dry matter production (DMP, g pot ${ }^{-1}$ ) of maize plants as a function of applied $\mathrm{P}$ rate $(\mathrm{mg} \mathrm{dm}-$ $\left.{ }^{3}\right)$ and pre-incubation time (d) of non-coated MAP $\left(\mathrm{MAP}_{1}\right)$ and coated MAP $\left(\mathrm{MAP}_{2}, \mathrm{MAP}_{3}\right.$ and $\left.\mathrm{MAP}_{4}\right)$. $\mathrm{MAP}_{2}$ is coated with a natural organic acid; $\mathrm{MAP}_{3}$ is coated with a synthetic organic acid; and $\mathrm{MAP}_{4}$ is coated with a peat humic organic acid. ${ }^{\circ}, *, * *$ indicate significant coefficients at $p<0.1 ; 0.05$ and 0.01 by the $\mathrm{t}$ test, respectively. 


\subsection{Dry matter production (DMP)}

The highest DMP among all fertilizers (33.8 $\left.\mathrm{g} \mathrm{pot}^{-1}\right)$ was estimated to occur when $1158 \mathrm{mg}$ of $\mathrm{MAP}_{1} \mathrm{dm}^{-3}$ was applied to the soil $120 \mathrm{~d}$ ahead of maize planting For the same fertilizer pre-application period of $120 \mathrm{~d}$, the required doses of $\mathrm{MAP}_{3}, \mathrm{MAP}_{4}$ and $\mathrm{MAP}_{2}$ would be 840,891 , and $765 \mathrm{mg} \mathrm{dm}^{-3}$ for DMPs of $29.8,29.5$ and $26.5 \mathrm{~g} \mathrm{pot}^{-1}$, respectively (Figure 7).

\section{Discussion}

\subsection{Kinetics of fertilizer P release in water}

In summary, the water solubility test that we carried out with the distinctly coated MAPs demonstrated that the $\mathrm{P}$ release from fertilizer granules could be related to the hydrophilicity or hydrophobicity of the coating material. Thus, the molecular characteristics of the humic acid $\left(\mathrm{MAP}_{4}\right)$, with an intermediate hydrophobicity, provided a more gradual release of $\mathrm{P}$ over time compared to the organic acids-coated fertilizers $\left(\mathrm{MAP}_{2}\right.$ and $\left.\mathrm{MAP}_{3}\right)$.

Recent studies using NPK fertilizer coated with different materials corroborate our findings of slower releases of coated MAPs. Lubkowski (2014) observed that the release of P from uncoated NPK was six times faster than from oligochitosan-coated NPK. Likewise, Lubkowski et al. (2015) observed that the $t_{1 / 2 P}$ of NPK coated with different amounts of biodegradable poly (butylene succinate) was 100 to 1000 times slower than that of uncoated NPK (55-60 min). Noppakundilograt et al. (2015) evaluated the solubility of P in water from trilayer-coated NPK with poly(vinyl alcohol)/cross-Chitosan/poly(acrylic acid-co-acrylamide) and observed that only $12 \%$ of $\mathrm{P}$ was released over 30 days, while conventional NPK released $100 \%$ in $12 \mathrm{~min}$.
The relationship between the hydrophilicity of the polymer coating and the release of $\mathrm{P}$ from the fertilizer granule to an aqueous medium is well known. Hana et al. (2009) examined a biodegradable starch/polyvinyl alcohol film as a coating for fertilizers and found higher water permeability through the coating with a higher proportion of polyvinyl alcohol. This effect can be partially explained by the increased hydrophilicity of the polyvinyl alcohol provided by the increasingly abundant -OH groups. Noppakundilograt et al. (2015), in a previous study of coated NPK fertilizer, observed that the increase of hydrophilic groups allowed a greater expansion of the hydrogel poly(vinyl alcohol)/cross-Chitosan/poly(acrylic acid-co-acrylamide) and higher water absorption. However, the hydrophilicity of the polymer coatings may depend on the $\mathrm{pH}$ of the surrounding solution (Ahmad et al., 2015).

The slower $\mathrm{P}$ release rates of the coated fertilizer are usually a result of physical and chemical barriers. According to Wu and Liu (2008) the dissolution mechanism of coated fertilizers includes three stages: 1 ) the water penetrates through the porous coating; 2) the nutrients are gradually dissolved in the solution; and 3) the solution diffuses through the porous coating. Thus, issues such as porosity (Tomaszewska and Jarosiewicz, 2004; Silva et al., 2012), thickness of the coating layer (Jia et al., 2013; Lubkowski, 2014; Lubkowski et al., 2015), and composition of the organic polymer (Wu and Liu, 2008; Tyliszczak et al., 2009; Hana et al., 2009) determine the P diffusion coefficient from the granule to the soil (Du et al., 2006; Lubkowski, 2014; Ahmad, 2015).

Based on these studies and our own findings, it can be hypothesized that the humic acid coating allowed an initial hydration of the coating, but in a following phase, the dissolution of the MAP fertilizer may have been slowed down by the thin film of soy oil previously adsorbed to the fertilizer granules. Thus, it appears 
that instead of searching for compounds of variable composition and hydration capacities, it may be more effective and practical to use more than one coating material sequentially applied to the fertilizer granule. The products we use for the $\mathrm{MAP}_{4}$ coating offer the advantage of being natural, biodegradable products that offer no environmental risks. Furthermore, they are readily available products and can be acquired at competitive prices worldwide. The use of peat humic acid may be questioned on the grounds of possible environmental impacts derived from its extraction/ mining from nature. However, such a limitation can possibly be overcome by using natural humic-like substances that are chemically similar to humic acids and can be synthesized from industrial, plant-derived biochar (Trompowski et al., 2005).

\subsection{Greenhouse pot experiment}

The uncoated MAP has a high rate of P release (Figure 3), and it leads to a fast increase in the concentration of $\mathrm{P}$ in the soil solution (Silva et al., 2012). Nevertheless, the quick release may be followed soon afterwards by low P availability due to the rapid adsorption and the low reversibility of the bonding of phosphate ions to $\mathrm{Al}$ and $\mathrm{Fe}$-hydroxy (oxides) (Parfitt, 1989; Novais and Smyth, 1999; Khatiwada et al., 2012; Abdala et al., 2015a), which is particularly the case in acid tropical soils.

The coated fertilizers we evaluated provided greater soil $\mathrm{P}$ availability over time (Figure 3 ). The release of $\mathrm{P}$ from the polymer-coated fertilizer when in contact with the soil may also be influenced by the biodegradability of the polymer (Ao et al., 2013; Jia et al., 2013; Lubkowski et al., 2015) and by the characteristics of the soil solution surrounding the granule (ionic strength; temperature; $\mathrm{pH}$ conditions) (Hanafi et al., 2000; Tyliszczak et al., 2009; Ahmad et al.,
2015). This fact contributes to the delayed release of the coated $P$ fertilizers.

The dissolution of a P fertilizer creates two distinct zones around the granule as it is dissolved by the soil solution (Hedley and McLaughlin, 2005). For uncoated highly soluble fertilizers like $\mathrm{MAP}_{1}$, it is likely that the rapid hydration and dissolution increased the concentration of $\mathrm{P}$ in the soil solution in close proximity to the granule, saturating the absorbent surface and thus allowing quickly diffusion of $\mathrm{P}$ towards the bulk soil. In this P-saturated zone, $\mathrm{P}$ precipitates are likely to form, thus reducing its solubility. Even in acid soils it appears that $\mathrm{Ca}-\mathrm{P}$, in addition to Fe-P and Al-P, precipitates are formed, and this is an important way of interfering with $\mathrm{P}$ availability (McLaughlin et al., 2011; Khatiwada et al., 2012). Further away from the fertilizer granule, a P-unsaturated zone exists, where the $\mathrm{P}$ concentration in solution is below the soil maximum adsorption capacity. Specific high-energy adsorption reactions of $\mathrm{P}$ with soil minerals dominate in this region and are intensified with increasing P contact time with the inorganic soil components, especially with mineral non-silicate clay ( $\mathrm{Fe}$ and $\mathrm{Al}$ oxides), providing a form of $\mathrm{P}$ that is unavailable to plants.

In our double-walled apparatus used for preventing direct contact of fertilizer-P with the soil, the first Psaturated region was likely to occur in the internal soil core, and the P-unsaturated region could be formed in the external bulk soil. Assuming so, the slower release of $\mathrm{P}$ from the granules by our MAP-coated fertilizers may have reduced the formation of $\mathrm{P}$ precipitates in the P-saturated zone and favored a more continuous movement of $\mathrm{P}$ from the inner soil core to the bulk soil. This is supported by the fact that the Delta P values for the uncoated $\mathrm{MAP}_{1}$ were lower than those found for $\mathrm{MAP}_{2}, \mathrm{MAP}_{3}$ and $\mathrm{MAP}_{4}$ (Figure 4). Therefore, the gradual solubilization of the coated MAPs allowed a greater difference in concentrations of $\mathrm{P}$ between the internal and external soil cores, thus providing a more 
constant supply of P towards the bulk soil where the maize roots were developing.

Phosphorus uptake and maize plant dry matter accumulation were significantly affected by the doses and pre-incubation times of MAP fertilizers (Figure 5 and 6). In general, CSRFs favored P uptake, plant growth and P use efficiency. Several studies with different plants have shown that when the $\mathrm{P}$ source is coated, there is greater $\mathrm{P}$ uptake by plants, similar to the findings of our study. Pauly et al. (2002) found that after 45 days of barley cultivation, MAP coated with polyethylene film favored $4.21 \%$ more $\mathrm{P}$ uptake by the plants in comparison to uncoated MAP. Chagas et al. (2015) studied MAP coated with soluble anionic polymers and found $31.2 \%$ more $P$ uptake by lettuce plants with respect to uncoated MAP. The experimental evidence with plants has not always shown consistent results. Figueiredo et al. (2012) working with uncoated MAP and coated MAP (Kimcoat $($ ) found higher productivity and DMP of maize plants for coated MAP. Silva et al. (2012) found no difference in the DMP of maize plants with different doses of P using MAP coated with a polymer (Phosmax ${ }^{\circledR}$ ) and uncoated MAP. Such inconsistencies may have resulted from the distinct effectiveness of the coating material, initial soil P levels, fertilizer type and dose, and the soil mineralogy.

An intriguing finding of our study is the fact that at short pre-incubation times and high MAP doses, the uncoated MAP fertilizer led to a greater DMP by maize plants than the coated MAP fertilizers. This effect might be related to the pulse of $\mathrm{P}$ into the soil solution on the very first day (short pre-incubation time and high dose) by the uncoated fertilizer, favoring initial plant $\mathrm{P}$ uptake and growth. When lower $\mathrm{P}$ doses were used and there were longer $P$ contact times with the soil, the conversion of available P to less available $\mathrm{P}$ forms is expected, particular in soil zones more distant from the fertilizer granule (Khatiwada et al.,
2011). Detailed studies of the $P$ forms in this soil using synchrotron $\mathrm{K}$-edge XANES found that most $\mathrm{P}$ in a non-calcareous soil was bound to $\mathrm{Fe}$, and a small proportion was bound to $\mathrm{Ca}$. At longer incubation times (6 months), less $\mathrm{P}$ was found in adsorbed, plant available forms, and more stable $\mathrm{P}$ minerals were observed in the granular MAP treatment broadcast onto the soil surface. At the other end of the spectrum, the lowest DMP among the coated fertilizers was found for the plants of the $\mathrm{MAP}_{2}$ treatment, which may have resulted from it having the slowest $\mathrm{P}$ release kinetics. This too slow release likely resulted from its high hydrophobicity and may have limited $\mathrm{P}$ movement from the granule into the bulk soil when $\mathrm{MAP}_{2}$ had shorter pre-incubation times (high initial plant demand was not met by the initial slow P release). Therefore, limited P movement occurred into the inner soil core and then into the outer soil core where maize roots were growing.

Among the three major nutrients $(\mathrm{N}, \mathrm{P}$ and $\mathrm{K}), \mathrm{P}$ is the only one that is non-renewable and has no alternative sources, except the management of biogeochemical cycling (Childers et al., 2011; Alamgir and Marschner, 2016). Taken together with this fact, the current use and rate of $\mathrm{P}$ application can cause a peak of production by 2030 (Cordell et al., 2009). Thus, more efficient handling and environmentally safe and sustainable $\mathrm{P}$ use is required. The efficient management of P may be achieved through distinct ways involving strategies in the plant/rhizosphere/soil continuum (Shen et al., 2011), and it may also be improved by the use of CSRFs (McLaughlin et al., 2011).

In the current study, it was observed that the maximum economical production efficiency ( $90 \%$ DMP) was obtained by the conventional uncoated MAP; however, it was reached at a cost of a much higher $P$ dose $\left(1116 \mathrm{mg} \mathrm{dm}^{-3}\right)$. Plants fertilized with coated MAP fertilizers accumulated slightly less DMP than those fertilized with $\mathrm{MAP}_{1}$, but they required lower 
$\mathrm{P}$ doses to do so $\left(\mathrm{MAP}_{2}: 765 \mathrm{mg} \mathrm{dm}{ }^{-3} ; \mathrm{MAP}_{3}: 840\right.$ $\mathrm{mg} \mathrm{dm}{ }^{-3}$ and $\left.\mathrm{MAP}_{4}: 825 \mathrm{mg} \mathrm{dm}^{-3}\right)$. Additionally, CSRFs showed agronomic efficiencies varying from 3 to $13 \%$ greater than $\mathrm{MAP}_{1}$, and the recovery of applied $\mathrm{P}$ by maize plants ranged from 32 to $49 \%$ higher than MAP $_{1}$ (data not shown). This might have occurred because lower doses of coated MAP warranted a more gradual but more constant release of $\mathrm{P}$ into the soil, thus promoting a more efficient use of $\mathrm{P}$ by the plants . The distinct agronomic performances obtained by applying MAP fertilizers before planting suggest a management strategy more operationally efficient to be further analyzed by farmers that are used to broadcasting soluble fertilizers on the soil surface well ahead of the planting time. Despite the fact that $\mathrm{MAP}_{1}$ provided $90 \%$ DMP by the maize plant when it was applied $79 \mathrm{~d}$ before planting (for coated MAPs it varied from 53 to $69 \mathrm{~d}$ ), the dose required to obtain this effect was considerably higher because there is the need to saturate the soil minerals so that subsequent $\mathrm{P}$ released from the granule will be more available to plants. This strategy, however, undermines $\mathrm{P}$ use efficiency by plants and is less sustainable in the long term. Higher surface applied P doses also offer greater risk of losses of dissolved reactive $\mathrm{P}$ through runoff and the eutrophication of surface water bodies (Shoumans et al., 2013)

\section{Conclusions}

Overall, the coating of granular monoammonium phosphate (MAP) fertilizer with organic acids modifies the pattern of $P$ release, the movement from the fertilizer granule to the soil and $\mathrm{P}$ availability to plants over time. This resulted in greater P use efficiency by plants fertilized by coated MAP most of the time. The longer pre-incubation of MAP fertilizers may result in less P availability and plant growth, especially of uncoated MAP. This will probably be magnified in broadcast applications in clay, oxidic soils with low initially available P. By choosing coatings with distinct characteristics, it is possible to modulate $\mathrm{P}$ release by soluble $\mathrm{P}$ fertilizers such as MAP and to favor plant uptake over the formation of less available $\mathrm{P}$ forms, thus improving the efficiency of use of soluble fertilizer P.

\section{Acknowledgements}

The authors thank Profs. Richard Bell and Robert J. Gilkes for useful review and suggestions and the Kimberlit Company for providing the commercial coated MAP fertilizers ( $\mathrm{MAP}_{2}$ and $\left.\mathrm{MAP}_{3}\right)$. Finally, the authors are grateful to two anonymous reviewers for their valuable questions and suggestions, which certainly improved the final quality of this work.

\section{References}

Abdala, D. B., Northrup, P. A., Arai, T., Sparks, D. L. 2015a. Surface loading effects on orthophosphate surface complexation at the goethite/water interface as examined by extended X-ray Absorption Fine Structure (EXAFS) spectroscopy. J. Colloid Interf. Sci. 437, 297-303.

Abdala, D.B., Northrup, P.A., Vicentin, F.C., Sparks, D.L., 2015b. Residence time and $\mathrm{pH}$ effects on the bonding configuration of orthophosphate surface complexes at the goethite/water interface as examined by Extended X-ray Absorption Fine Structure (EXAFS) spectroscopy. J. Colloid Interface Sci. 442, 15-21.

Ahmad, N.N.R., Fernando, W.J.N., Uzir, M.H. 2015. Parametric evaluation using mechanistic model for release rate of phosphate ions from chitosan coated phosphorus fertilizer pellets. Biosyst. Eng. 129, 78-86. 
Alamgir, M., Marschner, P. 2016. Changes in P pools over three months in two soils amended with legume residues J. Soil Sci. Plant Nutr. 16 (1), 76-87.

Alvarez, V.H., Novais, R.F., Dias, L.E., Oliveira, J.A. 2000. Determinação e uso do fósforo remanescente. B. Inf. Soc. Bras. Ci. Solo. 25, 27-32.

Ao, L., Qin, L., Kang, H., Zhou, Z., Su, H. 2013. Preparation, properties and field application of biodegradable and phosphorus-release films based on fermentation residue. Int. Biodeter. Biodegr. 82, 134-140.

Bortolin, A., Aouada, F.A., Moura, M.R., Ribeiro, C., Longo, E., Mattoso, L.H.C. 2012. Application of Polysaccharide Hydrogels in Adsorption and Controlled-Extended Release of Fertilizers Processes. J. App. Polym. Sci. 123, 2291-2298.

Braga, J.M., Defelipo, B.V. 1974. Determinação espectrofotométrica de fósforo em extratos de solos e plantas. Rev. Ceres. 113, 73-85.

Chagas, W.F.T., Emrich, E.B., Guelfi, D.R., Caputo, A.L.C., Faquin, V. 2015. Productive characteristics, nutrition and agronomic efficiency of polymer-coated MAP in lettuce crops. Rev. Ciênc. Agron. 46, 266-276.

Chien, S., Prochnow, L., Cantarella, H. 2009. Recent developments of fertilizer production and use to improve nutrient efficiency and minimize environmental impacts. Adv. Agron. 102, 267-322.

Childers, D. L., Corman, J., Edwards, M., Elser, J.J. 2011. Sustainability challenges of phosphorus and food: solutions from closing the human phosphorus cycle. Bioscience. 61, 117-124.

Cordell, D., Drangert, J. O., White, S. 2009. The story of phosphorus: global food security and food for thought. Global Environ. Change. 19, 292-305.

Dong, Y. J., He, M.R., Wang, Z.L., Chen, W.F., Hou, J., Qiu, X.K., Zhang, J.W. 2016. Effects of new coated release fertilizer on the growth of maize.
J. Soil Sci. Plant Nutr. http://dx.doi.org/10.4067/ S0718-95162016005000046.

Du, C., Zhou, J., Shaviv, A. 2006. Release Characteristics of nutrients from polymer-coated compound controlled release fertilizers. J. Polym. Environ. $14,223-230$.

Figueiredo, C. C., Barbosa, D.V., Oliveira, S.A., Fagioli, M., Sato, J.H. 2012. Adubo fosfatado revestido com polímero e calagem na produção e parâmetros morfológicos de milho. Rev. Ciênc. Agron. 43, 446-452.

Gonçalves, J.L.M., Firme, D.J., Novais, R.F., Ribeiro, A.C. 1985. Cinética de adsorção de fósforo em solos de cerrado. R. Bras. Ci. Solo. 9, 107-111.

Guedes, R.S., Melo, L.C.A., Vergütz, L., RodríguezVila, A., Covelo, E.F., Fernandes, A.R. 2016. Adsorption and desorption kinetics and phosphorus hysteresis in highly weathered soil by stirred flow chamber experiments. Soil Tillage Res. 162, $46-54$

Hana, M.M., Eltaib, S.M., Ahmad, M.B. 2000. Physical and chemical characteristics of controlled release compound fertiliser. Eur. Polym. J. 36, 2081-2088

Hana, X., Chena, S., Hub, X. 2009. Controlled-release fertilizer encapsulated by starch/polyvinyl alcohol coating. Desalination. 240, 21-26.

Hedley, M.J., McLaughlin, M.J. 2005. Reactions of phosphate fertilizers and by-products in soils. In: Sims J.T., Sharpley, A.N. (eds). Phosphorus: Agriculture and the environment. Agronomy Monograph Publisher, Madison, WI, vol. 46, pp: $181-252$.

Jia, X., Ma, Z., Zhang, G., Hu, J., Liu, Z., Wang, H., Zhou, F. 2013. Polydopamine film coated controlled-release multielement compound fertilizer based on mussel-inspired chemistry. J. Agric. Food Chem. 61, 2919-292. 
Johnson, C.M., Ulrich, A. 1959. Analytical methods for use in plant analysis, vol. 766. North Carolina State University Publisher, Raleigh, 53 p.

Khatiwada, R., Hettiarachchi, D.B., Mengel, G.M., Fei, M. 2006. Speciation of phosphorus in a fertilized, reduced-till soil system: in-field treatment incubation study. Soil Sci. Soc. Am. J. 76, 2006-2018.

Liang, R., Liu, M. Z., Wu, L. 2007. Controlled release NPK compound fertilizer with the function of water retention. React. Funct. Polym. 67, 769-779.

Lubkowski, K. 2014. Coating fertilizer granules with biodegradable materials for controlled fertilizer release. Environ. Eng. Manag. J. 13, 2573-2581.

Lubkowski, K., Smorowska, A., Grzmil, B., Kozłowska, A. 2015. Controlled-Release Fertilizer Prepared Using a Biodegradable Aliphatic Copolyester of Poly(butylene succinate) and Dimerized Fatty Acid. J. Agric. Food Chem. 63, $2597-2605$.

Ma, Z., Jia, X., Zhang, G., Hu, J., Zhang, X., Liu, Z., Wang, H., Zhou, F. 2013. pH-Responsive Controlled-Release Fertilizer with Water Retention via Atom Transfer Radical Polymerization of Acrylic Acid on Mussel- Inspired Initiator. J. Agric. Food Chem. 61, 5474-5482.

McLaughlin, M. J., McBeath, T. M., Smernik, R., Stacey, S. P., Ajiboye, B., Guppy, C. 2011. The chemical nature of $\mathrm{P}$ accumulation in agricultural soils implications for fertiliser management and design: an Australian perspective. Plant Soil. 349, 69-87.

Noppakundilograt, S., Pheatcharat, N., Kiatkamjornwong, S. 2015. Multilayer-Coated NPK Compound Fertilizer Hydrogel with Controlled Nutrient Release and Water Absorbency. App. Polym. 41249, 1-11.

Novais, R. F., Alvarez, V. V. H., Barros, N. F., Fontes, R. L. F., Cantarutti, R. B., Neves, J.C. L. 2007. Fertilidade do solo. Sociedade Brasileira de Ciên- cia do Solo Publisher, Viçosa, Minas Gerais, Brasil, $1017 \mathrm{p}$.

Novais, R. F., Neves, J. C. L., Barros, N. F. 1991. Ensaio em ambiente controlado. In: Oliveira, A. J., Garrido, W.E., Araújo, J.D., Lourenço, S. (eds). Métodos de pesquisa em fertilidade do solo, 1st ed. Embrapa-SEA Publisher, Brasília, DF, pp: 189-253.

Novais, R.F., Smith, T.J. 1999. Fósforo em solo e planta em condições tropicais. Sociedade Brasileira de Ciência do Solo Publisher, Viçosa, Minas Gerais, Brasil, 399 p.

Parfitt, R.L. 1978. Anion adsorption by soils and soil materials. Adv. Agron. 30, 1-50.

Paul, E.A., Clark, F.E. 1996. Soil microbiology and biochemistry, 2 ed. Academic Press Publisher, Califórnia, San Diego, 340 p.

Pauly, D. G., Nyborg, M., Malhi, S.S. 2002. Controlled-release $\mathrm{P}$ fertilizer concept evaluation using growth and $\mathrm{P}$ uptake of barley from three soils in a greenhouse. Can. J. Soil Sci. 82, 201210.

Raij, B. van, Quaggio, J.A., Cantarella, H., Ferreira, M.E., Lopes, A.S., Bataglia, O.C. 1987. Análise química de solos para fins de fertilidade, 1st ed. Fundação Cargill Publisher, Campinas, 170 p.

Ruiz, H. A. 2005. Incremento da exatidão da análise granulométrica do solo por meio da coleta da suspensão (silte+argila). Rev. Bras. Ciênc. Solo. 29, 297-300.

Santos, H. C., Oliveira, F. H. T., Salcedo, I.H., Souza, A.P., Silva, V.D.M. 2011. Kinetics of phosphorus sorption in soils in the state of Paraíba. R. Bras. Ci. Solo. 35, 1301-1310.

SAS Institute, Inc. 1989. SAS/STAT user's guide. Version 6, 4th ed., Vol. 2. SAS Institute, Inc. Publisher, Cary, NC. 
Schoumans, O.F., Chardon, W.J., Bechmann, M., Gascuel-Odoux, C., Hofman, G., Kronvang, B., Rubaek, G.H., Ulen, B., Dorioz, J.M. 2011. Mitigation options to reduce phosphorus losses from the agricultural sector and improve surface water quality: a review. Sci. Total Environ. 468, 1255-1266.

Shen, J.B., Yuan, L.X., Zhang, J.L., Li, H.G., Bai, Z.H., Chen, X.P., Zhang, W.F., Zang, F.S. 2011. Phosphorus dynamics: from soil to plant. Plant Physiol. 156, 997-1005.

Silva, A. A., Silva, T. S., Vasconcelos, A. C. P., Lana, R. M. Q. 2012. Influência da aplicação de diferentes fontes de MAP revestido com polímeros de liberação gradual na cultura do milho. Biosci. J. $28,240-250$.

Swift, R.S. 1996. Organic matter characterization. In: Sparks, D.L. (ed). Methods of Soil Analysis, part 3. Soil Science Society of America Publisher, Madison, pp: 1011-1069.

Teodorescu, M., Lungu, A., Stanescu, P. O., Neamţı , C. 2009. Preparation and properties of novel slow-release NPK agrochemical formulations based on poly(acrylic acid) hydrogels and liquid fertilizers. Ind. Eng. Chem. Res. 48, 6527-6534.
Tomaszewska, M., Jarosiewicz, A. 2004. Polysulfone coating with starch addition in CRF formulation. Desalination. 163, 247-252.

Trompowsky, P.M., Benites, V.M., Madari, B.E., Pimenta, A.S., Hockaday, W.C., Hatcher, P.G. 2005. Characterization of humic like substances obtained by chemical oxidation of eucalyptus charcoal. Org. Geochem. 36, 1480-1489.

Tyliszczak, B., Polaczek, J., Pielichowski, K. 2009. PAA-Based Hybrid Organic-Inorganic Fertilizers with Controlled Release. Polish J. of Environ. Stud. 18, 475-479.

Wu, L., Liu, M. 2008. Preparation and properties of chitosan-coated NPK compound fertilizer with controlled-release and

Zhang, M., Gao, B., Chen, J., Li, Y., Creamer, A.E., Chen, H. 2014. Slow-release fertilizer encapsulated by graphene oxide films. Chem. Eng. J. 255, 107-113. 